\title{
ELECTRONIC COURT AS A LEGAL AND ADMINISTRATIVE CATEGORY
}

The purpose of the article is to define the content and determine the essence of e-court as a legal and administrative category based on the analysis of the current domestic legislation, international normative legal acts and lawyers'opinions.

Methods. The validity of theoretical provisions and recommendations for further research, as well as the reliability of the results are ensured by the use of a set of philosophical, general and special research methods. The dialectical method of scientific cognition is used as the main general research method. Formal legal and systemic structural methods are applied for studying normative legal acts regulating e-court functioning. Logical semantic method is used when formulating definition constructions.

Results. It is noted that for the successful implementation of Electronic court project it is important not only to adopt relevant regulations and organizational measures, but also to develop a scientific concept within the science of administrative law. The content of the category has not got a legal definition in domestic law yet, although it has been legally formalized. The authors express the opinion that domestic legislation requires the concept formulation and consolidation at the legislative level - within the Law of Ukraine on the Judiciary and the Status of Judges. The importance of developing and adopting a separate law on distance e-justice is emphasized.

It is highlighted that further introduction of e-court in Ukraine involves systematic actions. They are technical and information support of courts; development of measures and systems to ensure information security; legal regulation of responsibility in case of violations; measures to prevent cybercrime; court staff trainings; educational campaign among population, monitoring of the system effectiveness and its constant modernization, etc. All the above allows considering e-court as an administrative and legal category.

Conclusions. As a result of the analysis, the authors suggest forming the awareness that e-court, as a legal and administrative category, is a component of e-government, a relatively independent and unique form of judicial administration and legal process based on information technology that provides a full cycle of documentation flow and litigation in an electronic format and has genuinely legal nature.

Key words: judiciary, judicial system, court, justice, e-court, e-justice. 
Svitlana Obrusna,

Professor

at the Department

of State and Legal Studies

of Bohdan Khmelnytsky

National University

of Cherkasy,

Doctor of Juridical

Sciences, Associate

Professor

Svitlanaobrusna@gmail.com

orcid.org/0000-0001-9354-923

Iryna Ivanova,

Associate Professor

at the Department

of Economy,

Entrepreneurship

and Marketing

of the Cherkasy State

Business College,

PhD, Associate Professor

irvik@gmail.com

orcid.org/0000-0002-4769-3620

\section{Introduction}

The rapid development of modern information technology has affected all fields of human life and has become invariable means of effective governance, including functioning of courts and administration of justice. E-court is a relatively new phenomenon in Ukraine, which is developing as a part of the generally accepted model of e-government in the modern information society, designed to provide the population with fast public services of high quality. However, practical implementation of both e-government and e-court may not be effective enough without proper scientific basis.

This issue is insufficiently studied within the science of administrative law, although taking into account its modern legal nature, which is based on V. Averyanov's man-oriented ideology (V. Averyanov, 2008), it is relevant for administrative and legal science as well as the field of administrative law.

The problems of electronic litigation in the domestic legal science are mostly considered at the level of research publications. Recently, the issue of e-court introduction has been in the centre of attention of mass media, social networks, court websites, etc. However, most publications are of a popular science, applied and publicistic nature, which can be explained by the novelty of the project.

At the same time, the problems of e-court functioning start being considered within the framework of legal science. Thus, O. Bryntsev (O. Bryntsev, 2016) was the first to summarize the experience and prospects for further e-court implementation in his monograph. In addition, the introduction of e-court has become the subject of research in the science of administrative law. In particular, V. Kutsenko analyses the concept of "administrative and legal support of e-court" and defines its content (V. Kutsenko, 2017). O. Ivanenko (O. Ivanenko, 2018) considers some issues of electronic litigation in the perspective of the study of the administrative and legal aspect of providing judicial services in his dissertation. Analyzing the problems and current trends of the judicial reform, R. Krusian (R. Krusian, 2018) explores the electronic court. A number of publications is devoted to the study of organizational and legal principles of implementation of the Unified 
judicial information and telecommunication system that has to secure effective e-justice (O. Bernazyuk, 2019).

There are studies that analyze certain procedural aspects of electronic litigation. Thus, O. Pohrebniak studies features of the introduction of electronic court in civil proceedings (O. Pohrebniak, 2018), including the procedure and problems of filing a lawsuit application in electronic form (O. Pogrebnyak, 2019). V. Ilkiv analyses features of the introduction of electronic court in the administrative process (V. Ilkiv, 2018).

However, there is a small number of monographs and dissertations on the above issues. Therefore, the problems of e-court implementation in terms of general administrative law should be considered in the following plane. Firstly, there is insufficient theoretical and legal basis for this project. Secondly, a proper conceptual and categorical apparatus has not been formed yet. It could become the scientific basis for the development and implementation of e-court. This also applies to the very concept of "electronic court".

There is no doubt that the experience of European scholars is valuable for domestic legal science and administrative science in particular, especially of the representatives of the countries with a high level of information technology integration in litigation and e-court development (Finland, Norway, Austria, Great Britain, Estonia, France, etc.). Dory Relling makes a deep analysis of the use of information technologies at different levels of court proceedings in Europe pointing out both achievements and perspectives (Dory Relling, 2012). Western European studies cover much more global implementation issues of electronic litigation, which is explained by both the level of the development of science and the practice of implementing e-court projects. Thus, Professor Tanel Kerikmäe, investigates the problems of using artificial intelligence in jurisprudence in Estonia and a number of other countries, expresses opinions on the relationship between legal principles and in particular the principle of the rule of law in the age of digitalization of the judicial system. His research gives us as a positive experience of Estonian e-justice, and focuses on the specific challenges the country and the society may face in the process of digitalization and automation (Tanel Kerikmäe, 2020).

We consider it expedient for domestic researchers and practitioners dealing with digitalization of the judicial system to pay attention to the conclusions of foreign scientists that modern technology must guarantee compliance with basic legal principles, integrity and authenticity of documents, data confidentiality and judicial independence systems (Gerillo, 2009).

The purpose of the article is to define the content and determine the essence of electronic court as a legal and administrative category. To achieve this goal, it is necessary to analyze the views of individual lawyers on this issue, current domestic legislation, international regulations, and domestic practice of e-court. 


\section{Generalization of scientists' views on the content of the "electronic court" concept}

Such terms as "electronic court", "electronic litigation", "e-justice", "digital court", "virtual court", "cyber court", etc. are used to denote the relations arising in the functioning of judiciary, and implemented with the involvement of modern information and telecommunication systems and software as a whole, as well as for the performance of individual procedural actions. It can be explained by the diversity of approaches to understanding the strategic purpose of introducing information technology in the judiciary, lack of a proper scientific concept of e-court, including the existing conceptual and categorical apparatus, normative consolidation of its content, etc.

According to the analysis of research publications, "e-court", "e-justice", "e-court procedure" are either considered as single-line terms or distinguished from one another. In addition, the authors of most publications do not define the concept of "electronic court", but name and characterize its structural elements. In addition, there are no common approaches to defining the content of the above concept.

Thus, A. Korshun notes that e-justice should be treated not only as a part of the concept of "justice", but also as one of the ways to implement it (A. Korshun, 2017). Such a vision enables us to consider "electronic court" as a category of administrative law.

$\mathrm{N}$. Teleshyna defines e-justice as a way of administering justice based on the use of information technology (Teleshyna, 2014). That is, the focus is on the trial, and therefore the understanding of e-justice is represented in the narrow sense.

We agree with A. Korshun's opinion that it is necessary to distinguish between the concepts of "electronic court" and "informatization of courts" (Korshun, 2017). The latter means that courts use computer technology in their activities as a handy tool, not a procedural one. Informational innovations concerning the ways of communication of people, participants in the process, placement of judicial acts on the Internet, provision of information on the progress of cases, etc. should not be considered a distinct definition of e-justice either.

According to N. Fedoseeva and M. Tchaikovska, the unification of courts into a single computer network, the existence of the Unified Register of Court Decisions, the availability of court websites is also not e-justice (Fedoseeva, Tchaikovska, 2011). We can agree with such approaches, however, these authors name important elements of e-justice in the understanding of its broader meaning.

Therefore, we support the idea of S. Romanenkova who believes that the concept of "e-justice" should be considered in both broad and narrow senses. In the narrow sense, the electronic court is the ability of the court and other participants in the trial to carry out the actions provided by regulations that directly affect the initiating and progress of the trial (Romanenkova, 2013).

A. Korshun offers a similar interpretation of e-court, noting that it is a set of different automated information systems (services) that allow court and other 
participants in the trial to carry out actions provided by regulations, mediated by electronic form of expressing procedural information and interaction litigation (Korshun, 2017).

In a broad sense, it is regulatory support and the organization of a set of different automated information systems and services that provide access to justice and its implementation (Romanenkova, 2013). The very understanding of the concept of "electronic court" in a broad sense should be considered as a legal and administrative category.

V.Kutsenko, analysing the problems ofadministrativeandlegal support of electronic court, interprets the concept of "electronic court" in terms of administrative law. It is a component of the information society, a relatively independent unique form of administrative litigation and legal process based on information technology with elements of artificial intelligence providing with a full cycle of documentation flow and litigation in electronic format, which has an originally legal nature (Kutsenko, 2017). In general, supporting the author, we believe that such wording needs some clarification.

Based on the analysis of scholars' views on the definition of "e-court", it is possible to define it in terms of the science of administrative law as a component of e-government, a relatively independent and unique form of judicial administration and legal process based on information technology providing with a full cycle of documentation flow and litigation in electronic format, which has an originally legal nature.

\section{Regulatory and legal consolidation of the concept of "electronic court"}

The content of the category "electronic court" has not received a legal definition in domestic law yet, although it has been legally formalized. It is stated in paragraph 9 of Art. 152 of the Law of Ukraine on the Judiciary and the Status of Judges (Law on the Judiciary and the Status of Judges, 2016). Some researchers express the opinion that its content is disclosed through the category "Unified judicial information and telecommunications system" in Art. 151 of this law (Law on the Judiciary and the Status of Judges, 2016). We cannot completely agree with it, as this article determines the structural elements of this category, but not the content.

International legal sources define the term "electronic court" and its structural elements. Thus, Recommendation CM/Rec (2009) 1 of the Committee of Ministers of the Council of Europe to the Member States of February 18, 2009 contains the definition of e-justice. It says that it is the use of ICT in the conduct of justice by all stakeholders of the judiciary in order to improve the efficiency and quality of the public service, in particular, to individuals and businesses. It includes electronic communication and data exchange, as well as access to judicial information (Recommendation CM/Rec (2009) 1 of the CM of the Council of Europe (2009)).

Recommendation Rec (2001) 3 of the Committee of Ministers of the Council of Europe determines the elements of e-justice: the possibility of initiating proceedings by electronic means; the possibility of taking further action in the proceedings within 
an electronic work-flow environment; the possibility of obtaining information about the state of the proceedings by having access to a court information system; the possibility of obtaining the results of the proceedings in electronic form; etc. (Recommendation Rec (2001) 3 of the CM of the Council of Europe).

As we can see, the domestic legal field requires the formulation of the concept of "electronic court" and its consolidation at the legislative level - within the Law of Ukraine on the Judiciary and the Status of Judges.

\section{Analysis of the implementation of e-court in Ukraine}

The idea of informatization of all spheres of public life including judiciary was laid down in Ukraine by the Law of Ukraine on the Basic Principles for the Development of an Information-Oriented Society in Ukraine for 2007-2015 (Law on the Basic Principles for the Development of an Information-Oriented Society in Ukraine for 2007-2015, 2007). One of the first concepts of "Electronic Court" in Ukraine was developed in 2012 by the State Enterprise "Information Judicial Systems" to develop the provisions of a number of laws, the Concept of the sectoral program of informatization of courts of general jurisdiction, other bodies and institutions of the judicial system and the Strategic Plan for the Ukrainian judiciary for 2013-2015.

Implementation of a pilot project on the exchange of electronic documents between the court and participants in the trial began in Sviatoshynskyi District Court of Kyiv and the Court of Appeal of Dnipropetrovsk region on October 15, 2012. Since 2015, the pilot project "Electronic Court" has worked in three courts of Odesa region (O. Bryntsev, 2016). In July 2016, project organizers presented its positive results and stressed that it was impossible to put it into judiciary practice because of the imperfections in legislation. It led to further changes in the regulatory framework, including the adoption of the Law of Ukraine on Amendments to the Commercial Procedure Code of Ukraine, Civil Procedure Code of Ukraine, the Code of Administrative Procedure of Ukraine and other legislative acts. In accordance with Article 151 and paragraph 8 of the first part of Article 152 of the Law of Ukraine on the Judiciary and the Status of Judges, the Concept of building a Unified Judicial Information and Telecommunication System was developed and approved.

On June 4, 2018 in 18 pilot courts of Ukraine, the testing of the subsystem of the Unified Judicial Information and Telecommunication System (UJTS) called "Electronic Court" began. On December 22, 2018 in all local and appellate courts the operation of the subsystem "Electronic Court" was launched in test mode (the Order of the State Judicial Administration of Ukraine "On testing the subsystem "E-court" in local and appellate courts", 2018).

The Unified Judicial Information and Telecommunication System was to become operational on March 1, 2019. The State Judicial Administration of Ukraine postponed the launch of the UJITS in accordance with the decision of the High Council of Justice and taking into account the results of discussions with courts, other bodies and institutions of the judiciary (the Decision of the Council of Judges of Ukraine 
"On the ambiguous practice of application by courts of the subsystem "Electronic Court", 2019). On November 7, 2019, the State Judicial Administration approved a new version of the Concept, which changed the approaches to building the Unified Judicial Information and Telecommunication System, its structure and determined the stages and deadlines, the final of which is dated 2023 (the Order of the State Judicial Administration of Ukraine "On ensuring the establishment and operation of the Unified Judicial Information and Telecommunication System", 2019).

Within the framework of the project implementation, summons are sent as SMS-messages to the parties in the proceedings; a person is given a chance to participate in the court session by video conference, copies of procedural documents are received in electronic form; automatic distribution of cases is exercised; recording of the hearings by technical means, electronic court records and document circulation, electronic archives, judicial statistics, generalization of judicial practice are carried out, etc.

But with the quarantine caused by the COVID-19 coronary virus pandemic, the Ukrainian judicial system faced both procedural and organizational challenges. Problems of technology and technical capabilities of courts, material and financial support have become no less critical. Currently, the main emphasis in the organization of courts functioning is on maintaining the balance between ensuring the right of access to justice and protecting participants in court proceedings, court visitors and court staff against the spread of acute respiratory diseases and COVID-19.

The pandemic has accelerated the process of judicial digitalization. During the quarantine, the courts have used Zoom, Skype, Google Meet in their work. But the problems of this software are insecurity against external interference, time constraints, identification of participants, and so on.

The adoption by the Verkhovna Rada of Ukraine of the Law of Ukraine on Amendments to Certain Legislative Acts Aimed at Providing Additional Social and Economic Guarantees in Connection with the Spread of Coronavirus Disease (COVID-2019) was in due time. According to it, the procedural codes have been amended including the fact that the litigants may participate in video conference outside the court using their own technical means (Law on Amendments to Certain Legislative Acts Aimed at Providing Additional Social and Economic Guarantees in Connection with the Spread of Coronavirus Disease (COVID-2019), 2020).

At the same time, there is a need to improve the procedure for a litigant identification and the possibility of full participation of this person as a party to the proceedings, submission of applications, motions and evidence in court by video conference without the court clerk on the part of the parties.

On April 8, 2020, the State Judicial Administration of Ukraine approved the "Procedure for working with technical means of videoconferencing during court hearings in administrative, civil and commercial proceedings with the participation of parties outside the court" (the Order of the State Judicial Administration of Ukraine, 2020). On April 23, 2020 the above procedure was adopted in a new wording, which 
indicated a fairly rapid response to problems in the organization of electronic court functioning.

Currently, a draft law on the organization of distance e-justice is being developed, which is actively discussed in the judicial community, media and social networks. We believe that the adoption of such a law is timely and will contribute to the successful implementation of the "Electronic Court" project.

The analysis of experts' opinions on problematic issues of further implementation of e-court enabled to point out the most essential ones. They include lack of interaction and duplication of functions between bodies providing e-court, imperfect software, technical and material capabilities of courts, corruption scandals, and insufficient experience of e-court implementation at the level of court administrations, judges, and participants in the process, ignorance of the litigants about the benefits and opportunities of electronic justice. It is clear that the introduction of quarantine measures has become a catalyst, which gives impetus to intensify work on developing e-court. However, this process can be slowed down due to both objective and subjective reasons.

Further implementation of e-court in Ukraine under the conditions of serious challenges involves systematic action to improve legislation; technical and information support of courts; development of measures and systems to ensure information security; legal regulation of responsibility in case of violations; taking measures to prevent cybercrime in this area; conducting trainings and workshops for court staff and other users of the system; extensive educational campaign among the population, systematic monitoring of the effectiveness of the system and its constant modernization. All the above allows considering e-court as a legal and administrative category, the importance of the issue of administrative and legal support of e-court for both science and the field of administrative law.

\section{Conclusions}

Thus, we believe that e-court is a category of administrative law, and from the point of view of science and administrative law it is a component of e-government, a relatively independent and unique form of judicial administration and legal process based on information technology that provides a full cycle of documentation flow and litigation in electronic format, which has a genuinely legal nature. Problems of e-court implementation in Ukraine should be the subject of research in administrative law, because its practical implementation may not be effective enough without a proper scientific basis.

\section{Bibliography:}

1. Авер'янов В. Оновлена українська адміністративно-правова доктрина на основі принципу верховенства права. Часопис Київського університету права. 2008. № 3. С. 9-14.

2. Бринцев О.В. «Електронний суд» в Україні. Досвід та перспективи : монографія. Харків : Право, 2016. 72 с.

3. Куценко В.Д. Поняття та зміст адміністративно-правового забезпечення електронного суду. Науковий вісник публічного і приватного права. 2017. Вип. 6. Т. 2. С. 3-9. 
4. Іваненко О.Ю. Адміністративно-правовий аспект надання судових послуг в Україні : автореф. дис. ... канд. юрид. наук : 12.00.07. Запоріжжя. 2018. 18 с.

5. Крусян Р.А. Реформування судоустрою в Україні: досвід, сучасність, тенденції : дис. ... канд. юрид. наук : 12.00.10. Одеса, 2018. 255 с.

6. Берназюк О. Єдина судова інформаційно-телекомунікаційна система. Підприємниитво, господарство і право. 2019. № 6. С. 326-329.

7. Погребняк О. Особливості запровадження електронного суду в цивільному процесі. Порівняльно-аналітичне право. 2018. № 1. С. 122-124.

8. Погребняк О. Особливості подання позовної заяви до суду в електронній формі. Матеріали Міжнародної науково-практичної конференції «Проблеми та стан дотримання i захисту прав людини в Україні». 2019. URL: file://C:/Users/6EDA 1/AppData/Local/ Temp/2qT0dK448O5pQkHqT78vezOJwrFhDqdp.pdf.

9. Ільков В. Впровадження електронного суду та застосування положень Кодексу адміністративного судочинства. Актуальні проблеми державотворення, правотворення та правозастосування. 2018. C. 38-40.

10. Relling D. E-justice: experiences with court IT in Europe. 2012. URL: http://www.iijusticia.org/docs/Dory.pdf.

11. Kerikmäe T., Nyman-Metcalf K. The rule of law and the protection of fundamental human rights in an era of automation. In: J.-S. Gordon (Ed.). Smart Technologies and Fundamental Rights. Brill (forthcoming). 2020.

12. Gerrillo A. E-Justice: Using Information Communication Technologies in the Court System / A. Gerrillo, H. Fabra. Hershey; New York : Information science reference, 2009. P. 13.

13. Коршун А. Розвиток в Україні електронного правосуддя в контексті взаємодії суду та інститутів громадянського суспільства: теоретико-правова характеристика. Національний юридичний журнал: теорія і практика. 2017. С. 20-24.

14. Телешина Н. Реалізація електронного правосуддя в Росії (на прикладі арбітражного суду Владимирської області). Арбітражний і ичивільний проиес. 2014. № 6. С. 44-50.

15. Федосєєва Н., Чайковська М. Електронне правосуддя в Росії і світі. Адміністратор cydy. 2011. № 3. С. 2.

16. Романенкова С. Поняття електронного правосуддя, його генеза і впровадження в правозастосовчу практику зарубіжних країн. Арбітражний $і$ циивільний процес. 2013. № 4. C. 31 .

17. Про судоустрій і статус суддів : Закон України від 02.06.2016. № 1402-VIII (зі змінами). URL: https://zakon.rada.gov.ua/laws/show/1402-19\#n1495.

18. Рекомендація CM/Rec (2009) 1 KM РЄ державам-членам від 18 лютого 2009 р. URL: zakon.rada.gov.ua/go/994_937.

19. Рекомендації Rec (2001) 3 KM PE. URL: sc.gov.ua/.../rekomendaciji.

20. Про основні засади розвитку інформаційного суспільства в Україні на 2007-2015 роки : Закон України від 9 січня 2007 р. № 537-V. URL: https://zakon.rada.gov.ua/ laws/show/537-16\#Text.

21. Про проведення тестування підсистеми «Електронний суд» у місцевих та апеляційних судах : Наказ ДСА України від 22.12.2018 № 628. URL: https://dsa.court.gov.ua/ userfiles/media/628_18.pdf.

22. Щодо неоднозначної практики застосування судами підсистеми «Електронний суд : Рішення Ради суддів України від 20.09.2019 № 75. URL: https://zib.com.ua/ua/ print/139493pro_neodnoznachnosti_zastosuvannya_sudami_sistemi_elektronni.html.

23. Про забезпечення створення і функціонування Єдиної судової інформаційнотелекомунікаційної системи : Наказ ДСА України від 07.11.2019 року № 1056. URL: https://dsa.court.gov.ua/userfiles/media/media/ECITC_Koncepcia.pdf. 
24. Про внесення змін до деяких законодавчих актів, спрямованих на забезпечення додаткових соціальних та економічних гарантій у зв'язку з поширенням коронавірусної хвороби (COVID-2019) : Закон України від 30.03.2020 р. № 540-IX. URL: https://zakon.rada.gov.ua/laws/show/540-20\#Text.

25. Порядок роботи 3 технічними засобами відеоконференцзв'язку під час судового засідання в адміністративному, цивільному та господарському процесах за участю сторін поза межами приміщення суду : Наказ ДСА України від 08.04.2020 р. № 169. URL: https://dsa.court.gov.ua/dsa/inshe/14/N_169_20.

\section{References:}

1. Averyanov, V. (2008). Onovlena ukrainska administratyvno-pravova doktryna na osnovi verkhovenstva prava [Updated Ukrainian administrative and legal doctrine based on the rule of law]. Chasopys Kyivskoho universytetu prava, no. 3, pp. 9-14 [in Ukrainian].

2. Bryntsev, O.V. (2016). Elektronnyi sud v Ukraini. Dosvid ta perspektyvy: monografiya ["Electronic court" in Ukraine. Experience and prospects]. Kharkiv: Pravo, 72 p. [in Ukrainian].

3. Kutsenko, V.D. (2017). Poniattia ta zmist administratyvno-pravovoho zabezpechennia elektronnoho sudu [The essence and content of legal and administrative support of electronic court]. Naukovyi visnyk publichnoho ipryvatnoho prava, no.6, v. 2, pp. 3-9 [in Ukrainian].

4. Ivanenko, O.Yu. (2018). Administratyvno-pravovyi aspekt nadannia sudovykh posluh $\mathrm{v}$ Ukraini [Legal and administrative aspect of providing judicial services in Ukraine] : avtoref. dys. ... kand. yuryd. nauk: 12.00.07. Zporizhzhia, 18 p. [in Ukrainian].

5. Krusian, R.A. (2018). Reformuvannia sudoustroyu v Ukraini: dosvid, suchasnist, tendentsii [Reforming judiciary in Ukraine: experience, modernity, trends] : dys. ... kand. yuryd. nauk: 12.00.10. Odesa, 255 p. [in Ukrainian].

6. Bernaziuk, O. (2019). Yedyna sudova informatsiyno-komunikatsiyna systema [Unified court information and telecommunication system]. Pidpryyemnytstvo, hospodarstvo $i$ pravo, no. 6, pp. 326-329 [in Ukrainian].

7. Pohrebniak, O. (2018). Osoblyvosti zaprovadzennia elektronnoho sudu v tsyvilnomy protsesi [The peculiarities of introducing e-justice in the civil process] Porivnialno-analitychne parvo, no. 1, pp. 122-124 [in Ukrainian].

8. Pohrebniak, O. (2019). Osoblyvosti podannia pozovnoi zayavy do sudu v elektronniy formi [The peculiarities of filing a lawsuit application in electronic form]. Materialy Mizhnarodnoi naukovo-praktychnoikonferentsii "Problemytastan dotrymanniaIzakhystupravliudyny vUkraini". URL: file:///C:/Users/6EDA 1/AppData/Local/Temp/2qT0dK448O5pQkHqT78vezOJwrFhD qdp.pdf [in Ukrainian].

9. Ilkov, V. (2018). Vprovadzennia elektronnoho sudu ta zastosuvannia polozhen Kodeksu administratyvnoho sudochynstva [Introduction of electronic court and application of the provisions of the Code of Administrative Procedure] Aktualni problem derzhavotvorennia, pravotvorennia ta pravozastosuvannia], pp. 38-40 [in Ukrainian].

10. Relling, D. (2012). E-justice: experiences with court IT in Europe. URL: http:// www.iijusticia.org/docs/Dory.pdf [in English].

11. Kerikmäe, T., Nyman-Metcalf, K. (2020). The rule of law and the protection of fundamental human rights in an era of automation. In: J.-S. Gordon (Ed.). Smart Technologies and Fundamental Rights. Brill [forthcoming] [in English].

12. Gerrillo, A. (2009). E-Justice: Using Information Communication Technologies in the Court System / A. Gerrillo, H. Fabra. Hershey; New York: Information science reference, p. 13 [in English]. 
13. Korshun, A. (2017). Rozvytok v Ukraini elektronnoho pravosuddia v konteksti vzayemodii sudu ta instytutiv hromadianskoho suspilstva: teoretyko-pravova kharakterystyka. [Development of e-justice in Ukraine in the context of interaction of court and the institutions of the civil society: theoretical legal characteristic] Natsionalnyi yurydychnyi zhurnal: teoriya $i$ praktyka, pp. 20-24 [in Ukrainian].

14. Teleshyna, N. (2014). Realizatsiya elektronnoho pravosuddia v Rosii [E-justice realization in Russia] (na prykladi arbitrazhnoho sudu Vladymyrskoi oblasti). Arbitrazhnyi i tsyvilnyi protses, no. 6, pp. 44-50 [in Ukrainian].

15. Fedoseeva, N., Tchaikovska, M. (2011). Elektronne pravosuddia v Rosii i sviti. [e-justice in Russia and the world] Administrator sudu, no. 3, p. 2 [in Ukrainian].

16. Romanenkova, S. (2013). Poniattia elektronnoho pravosuddia, yoho heneza i vprovadzennia $\mathrm{v}$ pravozastosovchu praktyku zarubizhnykh krayin [The notion of electronic justice, its genesis and implementation into legal practice of foreign countries]. Arbitrazhnyi $i$ tsyvilnyi protses, no. 4, p. 31 [in Ukrainian].

17. Pro sudoustrii i status suddiv. Zakon Ukrainy vid 02.06.2016 No. 1402-VIII zi zminamy [On the Judiciary and the Status of Judges. Law of Ukraine with amendments]. URL: https://zakon.rada.gov.ua/laws/show/1402-19\#n1495 [in Ukrainian].

18. Rekomendatsiya CM/Rec KM RE derzhavam-chlenam vid 18 liutoho $2009 \mathrm{r}$. [Recommendation CM / Rec (2009) 1 of the Committee of Ministers of the Council of Europe to the Member States]. URL: zakon.rada.gov.ua/go/994_937 [in Ukrainian].

19. Rekomendatsii Rec (2001) 3 KM RE [Recommendation Rec (2001) 3 of the Committee of Ministers of the Council of Europe] URL: sc.gov.ua/.../rekomendaciji [in Ukrainian].

20. Pro osnovni zasady rozvytku informtsiynoho suspilstva v Ukraini na 2007-2015 roky. Zakon Ukrainy vid 9 sichnia 2007 r. No. 537-V [Law on the Basic Principles for the Development of an Information-Oriented Society in Ukraine for 2007-2015] URL: https://zakon.rada.gov.ua/ laws/show/537-16\#Text [in Ukrainian].

21. Pro provedennia testuvannia pidsystemy "Elektronnyi sud" $u$ mistsevykh ta apeliatsiynykh sudakh. Nakaz DSA Ukrainy vid 22.12.2018 No. 628 [Order of the State Judicial Administration of Ukraine "On testing the subsystem "E-court" in local and appellate courts"]. URL: https://dsa.court.gov.ua/userfiles/media/628_18.pdf [in Ukrainian].

22. Shchodo neodnoznachnoi praktyky zastosuvannia sudamy pidsystemy "Elektronnyi sud" Rishennia Rady suddiv Ukrainy vid 20.09.2019 No. 75 [the Decision of the Council of Judges of Ukraine "On the ambiguous practice of application by courts of the subsystem "Electronic Court"]. URL: https://zib.com.ua/ua/print/139493pro_neodnoznachnosti_zastosuvannya_ sudami_sistemi_elektronni.html [in Ukrainian].

23. Pro zabezpechennia stvorennia i funktsionuvannia Yedynoi sudovoi informatsiinotelekomunikatsiinoi systemy. Nakaz DSA Ukrainy vid 07.11.2019 roku No. 1056 [the Order of the State Judicial Administration of Ukraine "On ensuring the establishment and operation of the Unified Judicial Information and Telecommunication System"]. URL: https://dsa.court.gov.ua/ userfiles/media/media/ECITC_Koncepcia.pdf [in Ukrainian].

24. Pro vnesennia zmin do deyakykh zakonodavchykh aktiv, spriamovanykh na zabezpechennia dodatkovykh sotsialnykh ta ekonomichnykh harantii u zvyazku $\mathrm{z}$ poshyrenniam koronavirusnoi khvoroby Zakon Ukrainy vid 30.03.2020 r. No. 540-IX [Law on Amendments to Certain Legislative Acts Aimed at Providing Additional Social and Economic Guarantees in Connection with the Spread of Coronavirus Disease (COVID-2019)]. URL: https://zakon.rada.gov.ua/laws/show/540-20\#Text [in Ukrainian].

25. Poriadok roboty $z$ tekhnichnymy zasobamy videokonferentszvyazku pid chas sudovoho zasidannia $\mathrm{v}$ administratyvnomu, tsyvilnomu ta hospodarskomu protsesakhz za uchasti storin poza 
mezhamy prymishchennia sudu. Nakaz DSA Ukrainy vid 08.04.2020 r. №. № 169 [Procedure for working with technical means of videoconferencing during court hearings in administrative, civil and commercial proceedings with the participation of parties outside the court, the Order of the State Judicial Administration of Ukraine]. URL: https://dsa.court.gov.ua/dsa/inshe/14/N_169_20 [in Ukrainian].

\title{
ЕЛЕКТРОННИЙ СУД ЯК АДМІНІСТРАТИВНО-ПРАВОВА КАТЕГОРІЯ
}

\author{
Світлана Обрусна, \\ професор кафедри державно-правових дисциплін \\ Черкаського національного університету імені Богдана Хмельницького, \\ доктор юридичних наук, доцент \\ orcid.org/0000-0001-9354-923 \\ Svitlanaobrusna@gmail.com \\ Ірина Іванова, \\ доцент кафедри економіки, підприємництва і маркетингу, \\ Черкаського державного бізнес-коледжу, \\ кандидат педагогічних наук, доцент \\ orcid.org/0000-0002-4769-3620 \\ irivik@gmail.com
}

Мета статті - на підставі аналізу чинного вітчизняного законодавства, міжнародних нормативно-правових актів, думок окремих правників визначити зміст $і$ сутність електронного суду як адміністративно-правової категорії.

Методи. Обтрунтованість теоретичних положень $i$ рекомендацій щзодо подальшого наукового дослідження теми, а також достовірність результатів забезпечено використанням сукупності філософських, загально- й спеціально-наукових методів. Як основний загальнонауковий метод використано діалектичний метод наукового пізнання. Під час дослідження нормативно-правових актів, щзо регулюють функціонування електронного суду, застосовано формально-юридичний та системно-структурний методи. У ході формулювання відповідних дефініційних конструкцій використано логікосемантичний метод.

Результати. Зазначено, щчо для успішного впровадження проєкту «Електронний суд» велике значення мають не лише прийняття відповідних нормативно-правових актів та проведення організаційних заходів, а й розроблення наукової концепції в межах науки адміністративного права. Нині не сформовані певні доктринальні підходи, належний понятійно-категоріальний апарат, який би став науковим підтрунтям подальшоі розробки і впровадження електронного суду. Це стосується $і$ самого поняття «електронний суд».

Зміст категорії «електронний суд» поки не отримав правового визначення у вітчизняному законодавстві, хоча сама вона законодавчо оформлена. Висловлено думку про те, шьо вітчизняне правове поле потребує формулювання поняття «електронний суд» та закріплення його на законодавчому рівні - в межах Закону Украӥни «Про судоустрій та статус суддів». Наголошено на важливості розроблення та прийняття окремого закону щчодо організащії дистаниійного електронного правосуддя. 
Зазначено, щуо подальше впровадження електронного суду в Украйні передбачає системні дії щуодо удосконалення законодавства; технічно-інформачійного забезпечення судів; розроблення заходів і систем забезпечення захисту інформаиії; правового регулювання питань відповідальності осіб за порушення у иій сфері; вжсття заходів щэодо попередження кіберзлочинності; проведення навчальних семінарів серед працівників апарату суду та інших користувачів системи; иироку просвітницьку роботу серед населення, систематичний моніторинг ефективності роботи системи та ї̈ постійну модернізацію тощо. Все вищевказане дає змогу говорити про електронний суд як адміністративноправову категорію.

Висновки. У результаті проведеного аналізу авторами запропоновано розуміти, що електронний суд як адміністративно-правова категорія $\epsilon$ складовою частиною електронного врядування, відносно самостійною та унікальною формою судового адміністрування $і$ юридичного прочесу, заснованою на інформаційних технологіях, що забезпечують повний цикл руху документації та розгляду судової справи в електронному форматі, щзо носить легальну юридичну природу.

Ключові слова: судова влада, судова система, суд, правосуддя, електронне правосуддя. 